\title{
A Study of Online Market in Airline: A Case Study in Mongolia
}

\author{
Bayanmunkh Nandinchimeg1, Ganzorig Munkhjin', Tsevegdorj Battsetseg2 \\ ${ }^{1}$ Master of Business Administration, College of Management, Da-Yeh University, Taiwan \\ ${ }^{2}$ School of Public Affairs and Management, National academy of governance, Mongolia
}

\begin{abstract}
How to cite this paper: Bayanmunkh Nandinchimeg | Ganzorig Munkhjin | Tsevegdorj Battsetseg "A Study of Online Market in Airline: A Case Study in Mongolia" Published in International Journal of Trend in Scientific Research and Development (ijtsrd), ISSN: 24566470, Volume-3 | Issue-4, June 2019, pp.700-701, URL: https://www.ijtsrd.c om/papers/ijtsrd23

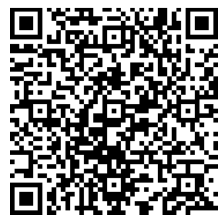
IITSRD23813
\end{abstract} 813.pdf

Copyright (C) 2019 by author(s) and International Journal of Trend in Scientific Research and Development Journal. This is an Open Access article distributed under the terms of the Creative Commons

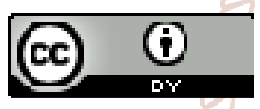
Attribution License (CC BY 4.0) (http://creativecommons.org/licenses/ by $/ 4.0$ )

The purpose of the research is to show what influence factors affect the level of CS in the airline industry and what are the main factors that affect the intention of the Mongolian passenger to buy OM through satisfaction. This study proposes hypothesis testing when trying to find answers to research questions and also identifies the demographic characteristics of the client and could influence consumer decisions to buy OM and CS. An OM is a paperless electronic document, especially in the airline industry [3]. Today, all major airlines use the electronic ticket sales method. When a customer buys or book a plane ticket over the phone or OM, the details of the reservation are saved on the computer. The benefit of OM is that it reduces the cost of buying a plane ticket by eliminating the need to print and send paper documents [1]. Another advantage is that consumers can easily compare ticket costs online without a transaction fee.

CS can be a basic standard of service performance and a possible fault-free standard for any business organization [4]. Satisfaction is a response to a perceived discrepancy between earlier expectations and perceived performance after consumption [5-7]. CS is defined by satisfaction with the product/service. Therefore, satisfaction is extremely important for OMs of products and services because a satisfied customer has a positive buying intention, such as repurchase, a positive word of mouth and long-term loyalty. For example: [8] found that between 35 and $40 \%$ of sales revenue from the $\mathrm{OM}$ comes from frequent visitors. Therefore, CS leads to customer loyalty and has a growth in market share and predicts greater penetration in the Airline Company market [9].

\section{Research Framework}

According to models and studies of OM satisfaction, several factors have been proposed to affect to $\mathrm{OM}$ satisfaction $[2,5-$ $7,10]$. The 4 factors in this study have been explored including: the information quality, payment security, interactivity and ease of use shown in Fig-1.

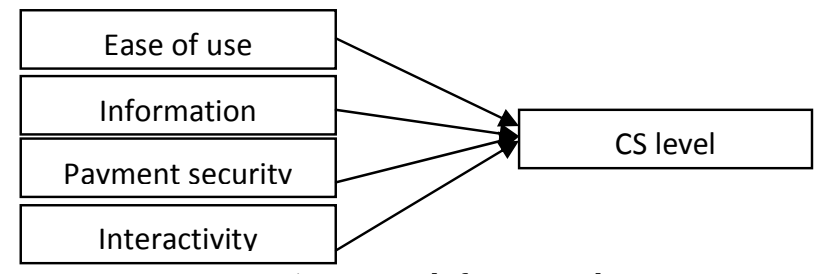

Fig-1: Research framework

H1: Ease of use has a positive effect on CS towards the purchase of OM.

H2: The quality of the website information has a positive effect on CS towards the purchase of OM.

H3: Payment security has a positive effect on CS towards the purchase of OM.

H4: Interactivity has a positive effect on CS towards the purchase of OM. 


\section{METHOD \& RESULTS}

\subsection{Measurement}

This study is measured by 4 variables that affect the satisfaction levels of airline passengers in Mongolia. The dependent variable in this study is CS and the independent variables are ease of use, quality of information, interactivity, and payment security.

The questionnaire has two parts; the first part is designed by the questions of the Likert scale, which consists in that the items are based on the research variables and the measurement of each element in the Likert range of 5 points.

\subsection{Data collection}

Before developing a formal questionnaire, a pilot test was conducted. The subjects for the pilot test were among airline employees and customers who were known to have used an airline's website, which included Hunnu and MIAT to reserve their ticket. The pilot questionnaire had 44 items that were reduced to 24 for the final survey. There were 22 invalid responses out of a total of 98 completed responses. One hundred thirty-eight valid questionnaires were used to prove they are adequate to test our hypotheses.

\subsection{Data analysis}

Demographic characteristics include age, gender, status, and income level. The statistics of the respondents show that most respondents are students (62.2\%) and non-managerial employees (18.4\%). Many of the respondents are between 21 and 35 years old $(84.7 \%)$ because most of the respondents are students and buy OM to study. Some demographic characteristics of the respondents are shown in Tab-1.

\begin{tabular}{|c|c|c|c|}
\hline Measure & Item & Frequency & Percentage \\
\hline \multirow{4}{*}{ Age } & Less than 21 & 7 & $7.1 \%$ \\
\hline & $21-35$ & 83 & $84.7 \%$ \\
\hline & $36-50$ & 7 & $7.1 \%$ \\
\hline & 51 and over & 1 & $1 \%$ \\
\hline \multirow{2}{*}{ Gender } & Male & 42 & $42.9 \%$ \\
\hline & Female & 56 & $57.1 \%$ \\
\hline \multirow[t]{3}{*}{$\begin{array}{c}\text { Current } \\
\text { status }\end{array}$} & $\begin{array}{l}\text { Managerial } \\
\text { level } \\
\text { Non- } \\
\text { managerial } \\
\text { level }\end{array}$ & $\begin{array}{l}13 \\
18\end{array}$ & $\begin{array}{l}13.2 \% \\
18.4 \%\end{array}$ \\
\hline & Student & 61 & $62.2 \%$ \\
\hline & Unemployed & 6 & $6.1 \%$ \\
\hline
\end{tabular}

Tab 1: Statistics of respondents' profiles

The hypotheses of the research model were tested using ANOVA and multiple regression equations provided by the SPSS computer program. Tab-2 shows that the correlation of the relationships between the study variables that are the 4 independent variables positively influence $\mathrm{CS}$.

\begin{tabular}{|c|c|c|c|c|c|}
\hline & IQ & PS & I & PEOU & SF \\
\hline IQ & 1 & & & & \\
\hline PS & $.658^{* *}$ & 1 & & & \\
\hline I & $.380^{* *}$ & $.360^{* *}$ & 1 & & \\
\hline EOU & $.775^{* *}$ & $.593^{* *}$ & $.280^{* *}$ & 1 & \\
\hline SF & $.622^{* *}$ & $.718^{* *}$ & $.746^{* *}$ & $.616^{* *}$ & $\mathbf{1}$ \\
\hline
\end{tabular}

Tab-2: Correlation matrix of variables

\section{CONCLUSION}

This study tried to examine the determinants of OM CS in Mongolia. The result of the investigation was supported by three factors and rejected two factors, the hypotheses are shown in Tab-4. In Mongolia's customers, the ease of use, interactivity and payment security of $\mathrm{OM}$ services are important determinants of OM CS.

\begin{tabular}{|c|c|}
\hline Hypotheses & Result \\
\hline H1 & Supported \\
\hline H2 & Not Supported \\
\hline H3 & Supported \\
\hline H4 & Supported \\
\hline
\end{tabular}

Tab-4: Result of Research Hypotheses

Customers of the Mongolian airline focus more on the interactivity and security of OM buys due to the lack of experience in the use of $\mathrm{OM}$ of the airline and feel more comfortable with the face-to-face interaction with the personnel of the airline. the airline and the more traditional payment system. It is also one of the reasons for the use of the Internet and $\mathrm{OM}$ is not common in Mongolia.

\section{Reference}

[1] Chen, C. F. (2007). Passenger use intentions for electronic tickets on international flights. Journal of Air Transport Management, 13(2), 110-115.

[2] Motlaq S.V., F. G., M. Kazemi, T.V. Motlaq, M.V. Motlaq. (2012). The Estimation of Customer's Electronic Trust (E-Trust) Toward Airline E-Ticketing in Iran using the Technology Acceptance Model(TAM). Midle Eastern Finance and Economics(16).

[3] Kurniawan, B. (2010). Factors affecting customer satisfaction in purchase decision on ticket online: a case study in air asia.

[4] Gerson, R. (1993). Measuring customer satisfaction: Crisp Learning.

[5] Eid, M. I. (2011). Determinants of e-commerce customer satisfaction, trust, and loyalty in Saudi Arabia. Journal of Electronic Commerce Research, 12(1), 78-93.

[6] Lau T.C, h.-L. K. a. H.-P. T. (2011). Airline e-Ticketing Service:How e-Service Quality and Customer Satisfaction Impacted Purchase Intention Medwell Journals, 5 (4), 200-2008.

[7] Merwe V.D, S. (2010). THE IMPACT OF ELECTRONIC SERVICE QUALITY DIMENSIONS ON CUSTOMER SATISFACTION.

[8] Rosen, S. (2001). Sticky website is key to success. Communication World, 18(3), 36.

[9] Yeoh, E., \& Chan, J. K. L. (2011). Malaysian Low Cost Airlines: Key Influencing Factors on Customers' Repeat Purchase Intention.

[10] Szymanski, D. M., \& Hise, R. T. (2000). E-satisfaction: an initial examination. Journal of retailing, 76(3), 309-322. 